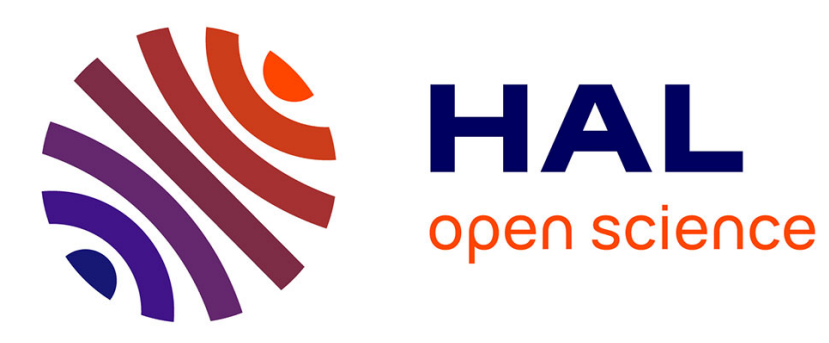

\title{
Fluid circulation and structural discontinuities inside Misti volcano (Peru) inferred from self-potential measurements.
}

Anthony Finizola, Jean-François Lénat, Orlando Macedo, Domingo Ramos, Jean-Claude Thouret, Francesco Sortino

\section{To cite this version:}

Anthony Finizola, Jean-François Lénat, Orlando Macedo, Domingo Ramos, Jean-Claude Thouret, et al.. Fluid circulation and structural discontinuities inside Misti volcano (Peru) inferred from selfpotential measurements.. Journal of Volcanology and Geothermal Research, 2004, 135, pp.343-360. 10.1016/j.jvolgeores.2004.03.009 . hal-01452539

\author{
HAL Id: hal-01452539 \\ https://hal.science/hal-01452539
}

Submitted on 2 Feb 2017

HAL is a multi-disciplinary open access archive for the deposit and dissemination of scientific research documents, whether they are published or not. The documents may come from teaching and research institutions in France or abroad, or from public or private research centers.
L'archive ouverte pluridisciplinaire HAL, est destinée au dépôt et à la diffusion de documents scientifiques de niveau recherche, publiés ou non, émanant des établissements d'enseignement et de recherche français ou étrangers, des laboratoires publics ou privés. 


\title{
Fluid circulation and structural discontinuities inside Misti volcano (Peru) inferred from self-potential measurements
}

\author{
Anthony Finizola ${ }^{\mathrm{a}, *}$, Jean-François Lénat ${ }^{\mathrm{a}}$, Orlando Macedo ${ }^{\mathrm{b}}$, Domingo Ramos ${ }^{\mathrm{b}}$, \\ Jean-Claude Thouret $^{\mathrm{a}}$, Francesco Sortino ${ }^{\mathrm{c}}$ \\ "Laboratoire Magmas et Volcans, Université Blaise Pascal et CNRS, OPGC, IRD, 5 rue Kessler, 63038 Clemont-Ferrand, France \\ 'Instituto Geofisico del Perú, Urbanización La Marina B19, Cayma, Arequipa, Peru \\ 'Istituto Nazionale di Geofisica e Vulcanologia, Sezione Palermo, Via Ugo La Malfa, I53, 90144 Palermo, Italy
}

\begin{abstract}
One of the seven potentially active andesite stratovolcanoes in southem Peru, Misti $(5822 \mathrm{~m})$, located $17 \mathrm{~km}$ northeast and $3.5 \mathrm{~km}$ above Arequipa, represents a major threat to the population ( $\sim 900,000$ inhabitants). Our recent geophysical and geochemical research comprises an extensive self-potential (SP) data set, an audio-magnetotelluric (AMT) profile across the volcano and $\mathrm{CO}_{2}$ concentrations in the soil along a radial profile. The SP survey is the first of its kind in providing a complete mapping of a large andesitic stratovolcano $20 \mathrm{~km}$ in diameter. The SP mapping enables us to analyze the SP signature associated with a subduction-related active volcano.

The general SP pattern of Misti is similar to that of most volcanoes with a hydrogeologic zone in the lower flanks and a hydrothermal zone in the upper central area. A quasi-systematic relationship exists between SP and elevation. Zones with constant SP/altitude gradients $(\mathrm{Ce}$ ) are observed in both hydrogeologic (negative $\mathrm{Ce}$ ) and hydrothermal (positive $\mathrm{Ce}$ ) zones. Transition zones between the different $\mathrm{Ce}$ zones, which form a concentric pattern around the summit, have been interpreted in terms of lateral heterogeneities in the lithology. The highest amplitudes of SP anomalies seem to coincide with highly resistive zones. The hydrothermal system $6 \mathrm{~km}$ in diameter, which extends over an area much larger than the summit caldera, may be constrained by an older, concealed collapse caldera. A sealed zone has apparently developed through alteration in the hydrothermal system, blocking the migration of $\mathrm{CO}_{2}$ upward. Significant $\mathrm{CO}_{2}$ emanations are thus observed on the lower flanks but are absent above the hydrothermal zone.
\end{abstract}

\section{Introduction}

Self-potential (SP) surveys carried out on shield volcanoes, such as Kilauea (Zablocki, 1976; Jackson

* Corresponding author. Osservatorio Vesuviano, INGVNapoli, via Diocleziano 328, 80124 Napoli, Italy.

E-mail address: finizola@ov.ingv.it (A. Finizola). and Kauahikaua, 1987), Piton de la Fournaise (Lénat, 1987; Malengreau et al., 1994, Michel and Zlotnicki, 1998), Karthala (Lénat et al., 1998), or on stratovolcanoes, such as Vesuvius (Di Maio et al., 1998) or Merapi, Lamongan (Aubert and Dana, 1994), show positive anomalies, a few hundreds to thousands millivolts in amplitude, associated with hydrothermal or active zones. These surface electric fields reflects 
some polarization mechanisms occurring at depth. Two kinds of mechanisms are assumed to create the anomalies on active volcanoes: electrokinetic and thermoelectric couplings (Corwin and Hoover, 1979). Electrokinetic coupling (or streaming potential) results from a fluid pressure gradient whereas thermoelectric coupling results from a temperature gradient. Theoretical considerations show that electrokinetic potentials, significantly larger than thermoelectric potentials (Corwin and Hoover, 1979), are considered as the major source of SP signals on volcanoes. Recent works have greatly improved our knowledge of the electrokinetic mechanisms. In natural rocks, electric layers with different electrical charge densities form at the water/mineral interface (Avena and De Pauli, 1996; Lorne et al., 1999a,b; Pengra et al., 1999; Revil and Leroy, 2001). The outer layer, called the diffuse layer, is generally positively charged (with a few exceptions noted by Guichet and Zuddas, 2003). The flow of the fluid drags positive charges of the electrical diffuse layer, creating a macroscopic current density and an electric field called the streaming potential. The current is therefore generally positive in the flow direction. This has been documented by laboratory experiments (e.g., Ishido and Mizutani, 1981; Jouniaux et al., 2000, for silica and volcanic rocks), theoretical works (Pride, 1994; Revil et al., 1999a,b; Lorne et al., 1999a,b; Revil and Leroy, 2001), and field data (e.g., Trique et al., 1999). As a consequence, the electrokinetic effect associated with the downflow of water in purely hydrogeological environments will result in negative SP anomalies at the surface, whereas the uprising of steam/liquid water in hydrothermal systems will generally result in positive anomalies. SP profiles extending from the summit to the lower flanks of active volcanoes (Sasai et al., 1997; Di Maio et al., 1998; Aubert et al., 2000; Finizola, 2002) show generally two major zones: a zone where SP is dominated by hydrothermal circulation, generally in the upper part of the edifice, and a zone dominated by hydrogeological circulations, generally in the lower flanks.

Our work is based on extensive SP mapping of the large Misti stratovolcano, $20 \mathrm{~km}$ in diameter. The survey consists of 10 radial profiles extending from the summit to the lower flanks. In addition, 32 audiomagnetotelluric (AMT) soundings provided a resistivity cross-section of the volcano along two SP profiles.
Diffuse $\mathrm{CO}_{2}$ in the soil was also measured along one SP profile. The large-scale SP signal pattern shows a typical partition in hydrogeological and hydrothermal zones. Both zones display widespread relationships between SP and elevation. The next section discusses the meaning of these SP/elevation relationships and shows how this parameter can be used to map the large-scale heterogeneity of the edifice.

\section{Relationships between SP and elevation}

A lateral SP variation at the surface can be caused by different phenomena: (1) a change in the distance to the source; (2) a variation in the source; or (3) heterogeneities in resistivity in the medium between the source and the surface.

(1) Simple changes in the distance to the source are well known in hydrogeological zone, and negative linear relationships between SP and elevation have been measured in many volcanic areas. At Kilauea volcano, Jackson and Kauahikaua (1987) have defined a correlation coefficient "Ce", which is the value of the SP gradient with elevation. It is calculated on portions of a profile where a linear relationship is observed. This negative SP/elevation relationship have been correlated with the piezometric head or with the thickness of the unsaturated zone, which tends to increase proportionally with elevation. This was confirmed by observations at boreholes and by electrical or electromagnetic soundings (Jackson and Kauahikaua, 1987; Aubert et al., 1990; Boubekraoui et al., 1998). Although the physical models of SP used to interpret these observations differs (percolation of vadose water to the water table for Zablocki, 1978, and Jackson and Kauahikaua, 1987, or flow of the water in the saturated zone for Fournier, 1983; Revil et al., 2003), they provide the same geological model for explaining a constant $\mathrm{Ce}$ in a hydrogeological zone: a water table whose depth increases regularly with elevation in a homogeneous medium. For example, on shield volcanoes built up by monotonous sequences of scoriae and lava flows, constant linear SP/elevation relationships are observed along distances up to several kilometers, e.g., on Kilauea (Jackson and Kauahikaua, 1987) and on Piton de la Fournaise (Lénat, 1987). Similar linear but positive relationships can also be observed 
in hydrothermal zones, but to our knowledge, they have never been analyzed in detail.

(2) SP variations can also be induced by changes in SP source. The streaming potential $(\Delta V)$ is governed by the Helmholtz-Smoluchowski equation:

$\Delta V=\frac{\varepsilon \zeta}{\eta \sigma_{\mathrm{f}}} \Delta P$

where $\varepsilon$ is the dielectric constant of the fluid, $\zeta$ is the zeta potential (the electrical potential at the solidliquid interface), $\eta$ is the viscosity of the fluid, $\sigma_{\mathrm{f}}$ is the electric conductivity of the fluid, and $\Delta P$ is the pressure difference. This equation is valid in saturated rocks where the fluid has a very high conductivity as opposed to that of the rock matrix and where surface conductivity (i.e., at the solid-liquid interface) is negligible. However, in rocks containing clays and zeolites, the surface conductivity may be high and must be taken into account (Revil et al., 2002a,b). The net effect is a $\Delta V$ decrease. Streaming potentials are also generated in partially saturated rocks and the Helmholtz-Smoluchowski equation has to be modified accordingly (Revil et al., 1999b; Guichet et al., 2003). The source parameters can be sorted between those concerning the fluids $\left(\varepsilon, \eta, \sigma_{\mathrm{f}}\right)$, the zeta potential, and the pressure. In a purely hydrogeological zone, the fluid is ground water, whose characteristics result mostly from water-rock interaction when rainwater circulates in the ground. The properties of the ground water should be influenced by the nature of the rocks and will not change significantly at the kilometer scale, except in the case of large lateral variations in lithology. Inside hydrothermal systems, more drastic changes are likely to occur in the properties of the fluids due to the contamination of the ground water by hot mineralized fluids. Theoretical and experimental works show that the zeta potential depends on the mineralogy (Revil et al., 1999a), the $\mathrm{pH}$ of the fluid (Lorne et al., 1999a,b), the salinity of the fluid (Pride and Morgan, 1991), and the temperature of the medium (Ishido and Mizutani, 1981). In the hydrogeological zone, variations of the zeta potential can be expected only if the mineralogy of the formations changes, whereas in the hydrothermal zone, it will vary according to hydrothermal conditions. As for the pressure, variations in the hydrogeological zone will be related to changes in the piezometric level with possibly large variations at the transition between a basal water table and a perched aquifer. In the hydrothermal zone, pressure can vary with parameters like the strength of convective cells, changes in permeability, etc.

(3) Finally, the distribution of electrical conductivity determines the far-field electric fields resulting from the electrokinetic phenomena. Low resistivities reduce the amplitude of the anomalies and resistivity heterogeneities distort the electric fields. Thus, the shape and the amplitude of anomalies measured at the surface are influenced by the distribution of the resistivities in the subsurface and at depth. The authors of several SP investigations carried out on Usu and Hokkaido Komaga-take volcanoes (Nishida and Tomiya, 1987; Matsushima et al., 1990) propose to relate drastic SP variations to lateral resistivity changes.

In interpreting SP data, we have to answer a series of questions raised by observations on most volcanoes, including Misti, which concern the relationships between SP and elevation both in hydrogeologic and hydrothermal zones:

(1) Why does a relationship between SP and elevation exist in many areas?

(2) Why does this relationship changes in distinct zones of a volcano?

As described above, changes of various parameters may account for the spatial variations of SP. However, a spatial change in Ce value represents a special case. In the hydrogeological zone, keeping a constant $\mathrm{Ce}$ requires a stable geological-hydrogeological pattern over a significantly large area. A change in the value of $\mathrm{Ce}$ between different areas must then be attributed to the variation of one or several parameters responsible for the SP signal recorded at the surface. On volcanoes, heterogeneities in resistivity are common, as shown by many electric and electromagnetic surveys. We therefore suspect that lateral changes in resistivity are one of the most frequent causes, sources for Ce variations. In addition, changes in resistivities often correspond to lithology changes, which can also affect the composition of fluids and of minerals, as well as the hydraulic gradient of the water table.

Although it is not possible in most of the cases to infer the origin of the observed Ce variations, mapping these variations allows us to emphasize heterogeneities within the edifices. 


\section{Geological setting}

Misti, an active stratovolcano of the Central Volcanic Zone of the Andean cordillera (CVZ in Fig. 1A), is located in southern Peru, $17 \mathrm{~km}$ NE of Arequipa, Peru's second largest city. Misti is one of the seven potentially active volcanoes of southern Peru which erupted since the Spanish conquest (Bullard, 1962; De
Silva and Francis, 1990). Four of them, Misti, Ubinas, Sabancaya, and Tutupaca are still fumarolic. Misti, $5822 \mathrm{~m}$ asl rises $3.5 \mathrm{~km}$ above the city of Arequipa, posing a major threat to the population $(\sim 900,000$ inhabitants).

Misti lies within a complex tectonic setting. It is surrounded by the Altiplano, the tectonic depression of Arequipa and by the dormant Chachani volcano

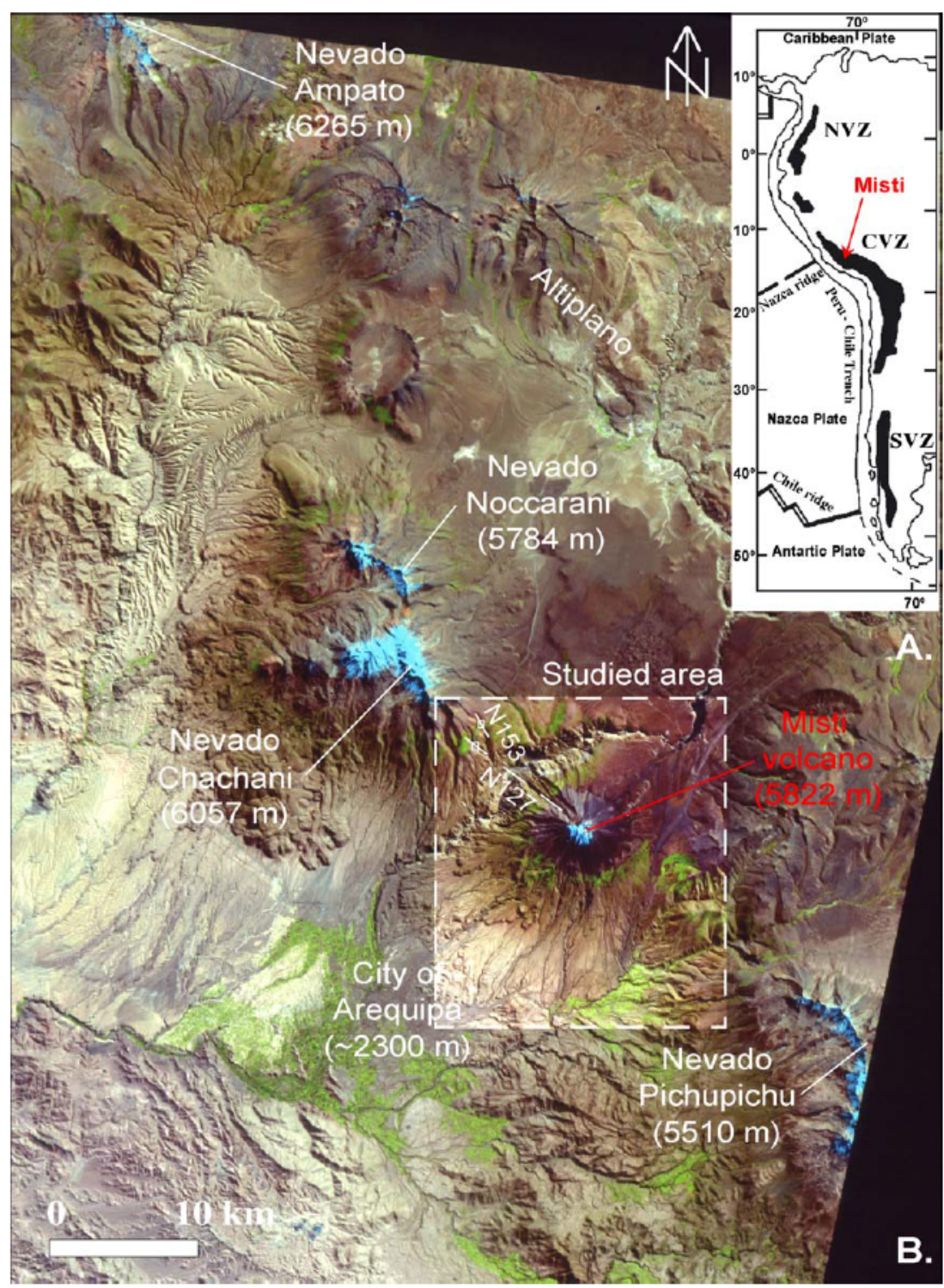

Fig. 1. (A) Location of Misti volcano in the Central Volcanic Zone (CVZ) of the Andes (the North Andean, NVZ, and the South Andean Volcanic Zone, SVZ, are also shown). (B) Landsat image showing the studied area and two active faults, which offset Holocene tephra across the Misti edifice. 


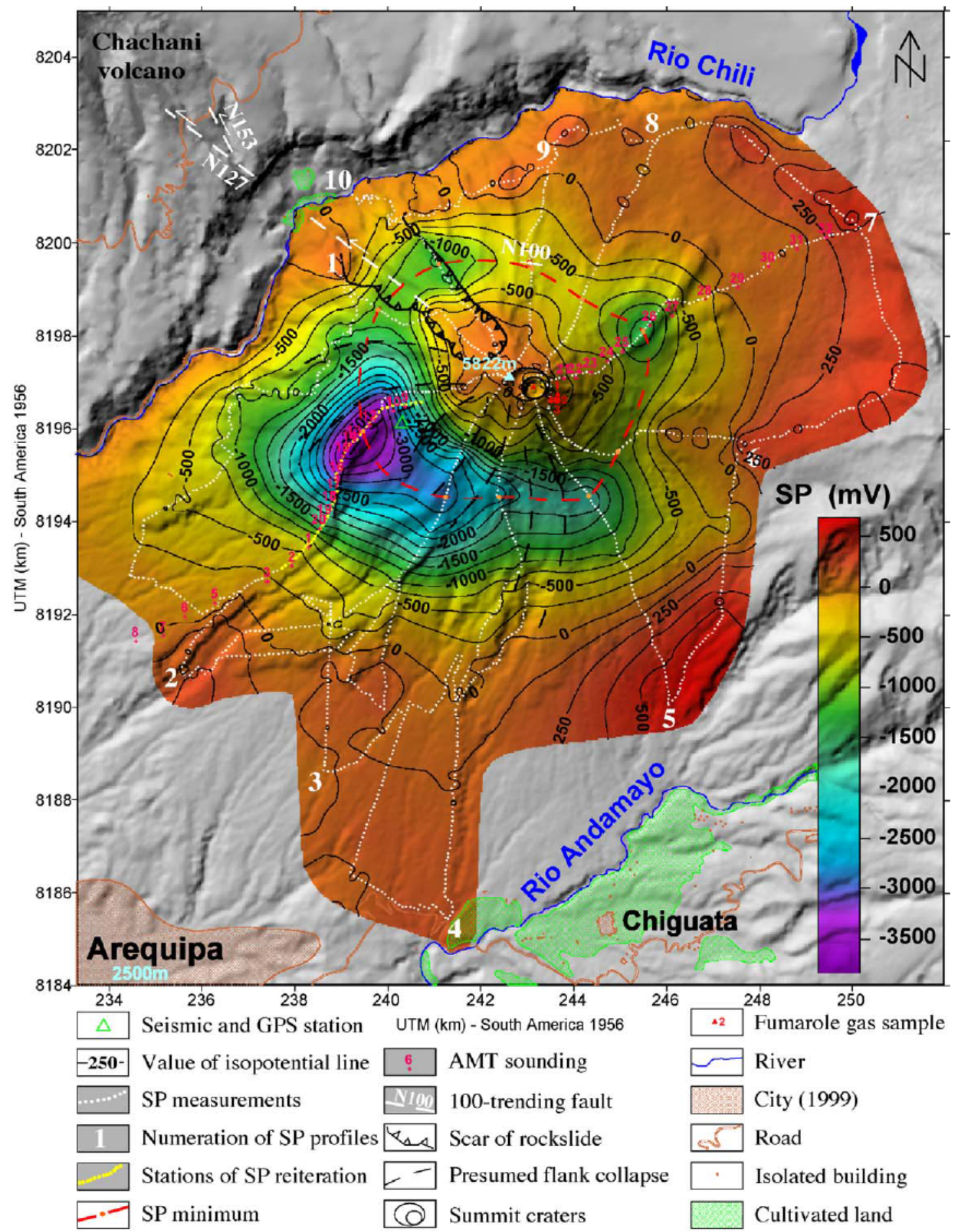

Fig. 2. SP map of Misti volcano superimposed on a shaded relief map showing volcano-structural features (DEM improved by SARinterferometry, courtesy of Jean-Luc Froger). 
and the extinct Pichupichu volcano (Fig. 1B). These three volcanoes are aligned on a WNW-ESE trending normal fault (N127 in Figs. 1B and 2). This fault offsets Holocene tephra on the Chachani flanks and, probably, the western flank of Misti volcano where it may have contributed to a rockslide scar (Thouret et al., 2001; Fig. 2). Another similar N153-trending normal fault offsets Holocene deposits on the flank of Chachani volcano (Figs. $1 \mathrm{~B}$ and 2). These two normal faults show a SW dipping and a moderate left-lateral strike-slip component (Thouret et al., 2001).

The growth of Misti volcano has been divided in four stages by Thouret et al. (2001). Misti is a composite edifice comprising an eroded stratovolcano termed Misti 1, partially overlapped by two stratocones termed Misti 2 and 3, and a summit cone, Misti 4. Misti 1 (833 to $112 \mathrm{kyr}$ ) consists essentially of lava flows and debris avalanche deposits. Misti 2 (112 to $40 \mathrm{kyr}$ ) is characterized by lava flows and dome-collapse deposits. At the end of stage 2, ca. 50 to $40 \mathrm{kyr}$ ago, the eruption of nonwelded ignimbrites of $3-5 \mathrm{~km}^{3}$ in volume is probably associated with the formation of a $6 \times 5$ $\mathrm{km}$ incremental caldera. Misti 3 stage (40 to 11 kyr) is mainly built up of lava flows, block-andash, and ash-flow deposits. Misti 3 also ended with the formation of a $2 \times 1.5 \mathrm{~km}$ summit caldera to which pyroclastic flows and falls deposits were linked. From $11 \mathrm{kyr}$ to present, Misti 4 stage corresponds to the growth of the summit cinder cone and to the formation of two summit craters. Pyroclastic flow, fall, and debris avalanche deposits are associated with this eruptive stage (Thouret et al., 2001).

The larger summit crater, $950 \mathrm{~m}$ wide, could have formed during the $2300-2050 \mathrm{yr}$ BP eruption of pumice fall and flows. The inner crater, $550 \mathrm{~m}$ across and $200 \mathrm{~m}$ deep, cut historical domes. It contains a 130-m-wide and 15-m-high andesitic plug. The present-day fumarolic activity is concentrated in three areas: (1) inside the nested crater, on the northern third of the lava dome, where diffuse degassing takes place and a maximum temperature of $221{ }^{\circ} \mathrm{C}$ was measured in December 1997, (2) in the northern and east-northern walls of the same crater with scarce fumaroles, and (3) along the uppermost southeast flank of the edifice, where several low temperature fumaroles were measured at 50 to $80{ }^{\circ} \mathrm{C}$ in September 1998 (Fig. 2).

\section{Data acquisition and processing}

\subsection{SP data}

During field campaigns in 1997 and 1998, a total of $167 \mathrm{~km}$ of SP profiles (1676 measurements, with $100 \mathrm{~m}$ spacing) were carried out. Data were collected along 10 radial profiles extending from the summit $(5822 \mathrm{~m}$ asl) to the lower flanks of the edifice ( $\sim 3000 \mathrm{~m}$ asl; Fig. 2). Two concentric profiles, located in the summit area and at the base of the lower flanks of the edifice, were carried out to ensure the closure of the radial profiles. A closure correction (below $20 \mathrm{mV}$ for three profiles, $50 \mathrm{mV}$ for five profiles, and as much as $100 \mathrm{mV}$ for two profiles) was calculated and distributed linearly on the profiles.

A monitoring profile, based on the SP map, crosses the highest negative anomaly of the survey and comprises 52 stations (yellow dots in Fig. 2) along the profile 2. Each station is pinpointed in the field in order to allow repeated observation of the measurements at the same location. The monitoring profile was established in August 1998, after an exceptionally dry period in southern Peru associated to the 19971998 El Niño event. Eight and thirty-eight months later, on April 1999 and October 2001 respectively, the profile was remeasured after two raining seasons (December to February).

The SP equipment consists of a high-impedance voltmeter, a pair of $\mathrm{Cu} / \mathrm{CuSO}_{4}$ nonpolarizing electrodes, and an insulated $\mathrm{Cu}$ cable $300 \mathrm{~m}$ long. During the field work, the electrical contact between the electrode, and the soil was tested before every SP measurement by measuring the resistance of the circuit. SP stations were georeferenced using a portable GPS navigation receiver.

Because the SP data coverage of Misti volcano is highly heterogeneous, with a high density of data along the profiles and large areas devoid of SP data, SP interpolation was made in several steps in order to produce an SP image of the entire volcano (Fig. 2). Firstly, the potential of the Chili River (lower end of profile 10) was taken as the $0 \mathrm{mV}$ reference; a 
value of $0 \mathrm{mV}$ was therefore attributed to the areas covered by the river. Secondly, an SP map of the entire area was constructed using a wide mesh (500 $\mathrm{m}$, i.e., five times larger than the sampling rate along the profiles) for interpolation. Thirdly, a $100 \times 100 \mathrm{~m}$ mesh SP map was constructed using the data along the profiles, $0 \mathrm{mV}$ values for the areas covered by the Chili river, and the grid values of the large mesh $(500 \mathrm{~m})$ SP map.

This procedure maintains the high frequency information along the profiles and provides a smooth interpolation between the profiles.

\subsection{Gas sampling}

Soil gases were also sampled in April 1999 concurrently with SP measurements along the SP monitoring profile (Fig. 2). The soil gases were pumped through a 2-mm-diameter copper tube inserted to a depth of $0.5 \mathrm{~m}$ and then injected in glass tubes to be analyzed by gas chromatography in the laboratory. The analytical error range in the $\mathrm{CO}_{2}$ concentration is $\pm 5 \%$ of the value.

\subsection{AMT data}

Thirty-two audio-magnetotelluric (AMT) soundings, measured along SP profiles 2 and 7 (Fig. 2), provide a SW-NE cross-section of Misti (Fig. 3). An abnormally thick snow cover at the time of the measurements (April-Mai 1999) hampered soundings in the summit area.

In the AMT method, natural electromagnetic fields are used to investigate the resistivity structure of the Earth (Vozoff, 1991). The amplitude, phase, and directional relationships between electric and magnetic fields on the surface depend on the distribution of the electrical resistivity in the subsurface. We used a

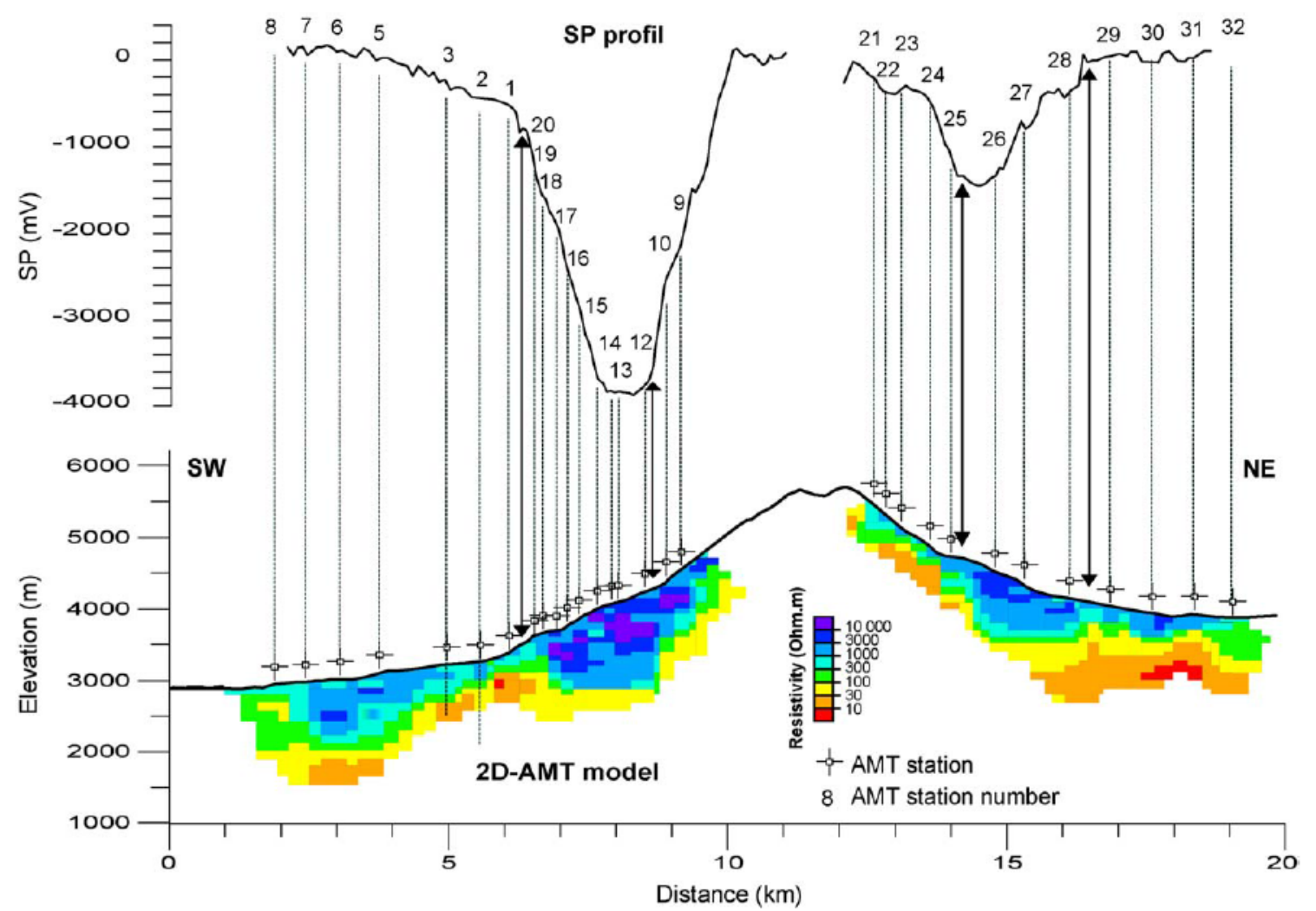

Fig. 3. Comparison between resistivity cross-section obtained by AMT soundings and corresponding SP profiles along a NE-SW transect across Misti edifice. Transect located on Fig. 2. 
Stratagem EH4 (Geometrics) equipment allowing to record data in the $92 \mathrm{kHz}-10 \mathrm{~Hz}$ frequency range. The Stratagem system records orthogonal electric and magnetic horizontal fields which are processed to provide tensor impedance measurements. When considering tensor measurements, we identify the transverse electric (TE) and transverse magnetic (TM) orthogonal components (e.g., Dobrin and Savit, 1988). For the TE mode, the electric field is parallel to the direction of the inferred 2D underlying structures. Assuming that the main structures of the Misti cone are concentric to the summit, we associate TE mode with the tangential electric field. The data were processed using the WinGLink ${ }^{\circledR}$ package from Geosystem. The resistivity cross-section presented on Fig. 3 results from a 2D smooth inversion. The WinGLink ${ }^{\circledR}$ routine uses a finite difference inversion code and inverts for a user-defined 2D mesh of resistivity blocks, extending laterally and downwards beyond the central detailed zone. The topography was included in the inversion, and TE and TM apparent resistivities and phases were inverted simultaneously.

\section{Data analysis}

Our extensive SP coverage of Misti volcano offers the unique opportunity to study SP signals at the scale of a large volcanic edifice about $20 \mathrm{~km}$ across and $2800 \mathrm{~m}$ in height.

\subsection{Main features of the $S P$ map}

SP profiles on Misti, as on the flanks of active volcanoes display an SP minimum corresponding to the transition between hydrogeologic and hydrothermal systems (Fig. 2). The prominent minimum observed halfway up the slope of the edifice (at $4400 \mathrm{~m}$ asl on average) points to the transition between the hydrogeologic SP signature of the lower flanks and the hydrothermal SP signature of the upper part of the edifice. The minimum contour outlines a roughly rectangular area, about $6 \times 5 \mathrm{~km}$ in size, approximately centered on the summit. The amplitude of the minimum varies to a large extent on the 10 radial profiles, from about $-3800 \mathrm{mV}$ on profile 2 to about $-700 \mathrm{mV}$ on profile 8 and 9 (Figs. 2 and 4).

Although the overall SP pattern of Misti does not show significant differences from SP patterns on similar volcanoes, it gives rise to specific questions. For example, what is the origin of the atypically high negative anomaly on profile 2 ? Why does the amplitude of the minima vary as much as sixfold between the 10 radial profiles, while the general shape of the edifice is that of a regular cone?

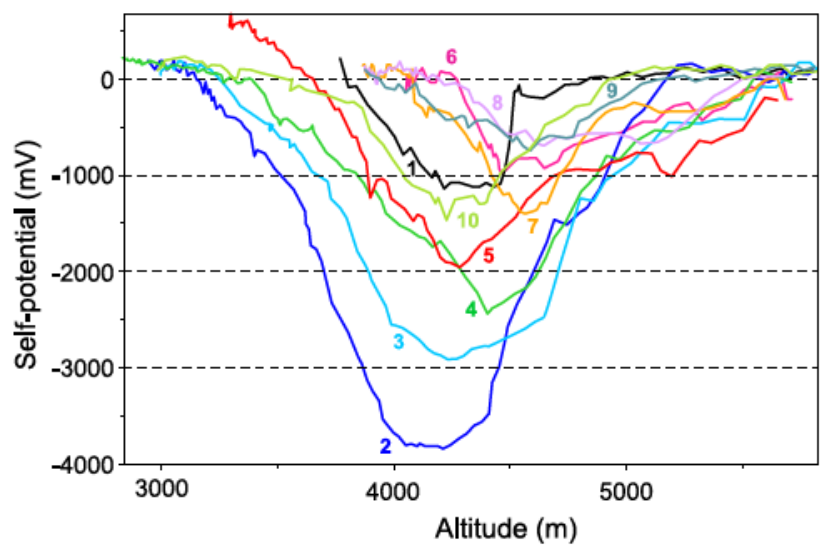

Fig. 4. Plot of the 10 radial SP profiles as function of elevation, illustrating large differences in amplitude between the profiles. The descending part of the curves corresponds to the hydrogeologic zone, whereas the ascending part reflects the (relatively) positive anomaly associated to the hydrothermal zone. Note that the highest amplitudes in the hydrothermal zone tend to equal that of the reference potential, taken on the Rio Chili at the base of the volcano. 


\subsection{Detailed analysis of SP profiles}

Fig. 4 displays SP values versus altitude for the 10 radial profiles. Large amplitude differences between the profiles as well as remarkable patterns can be noted:

- The middle part of the profiles have a "V" shape with an overall symmetry between the right and left branches.

- At low elevation (below 3200-4200 m asl according to the profile), the slope (Ce) of the curves is very low.

- At highest elevation (above $\sim 4800-5200 \mathrm{~m}$ asl depending on the profiles), the slopes of the curves are less regular and the relationship with the elevation sometimes disappears.
- On the descending as well as on the ascending branches of the "V" part of the curves, distinct segments are characterized by different Ce values (e.g., on radial 2 detailed in Fig. 5).

- Incidentally, the signal/noise ratio of the SP data on the profiles is fair (except for the lowest part of the edifice).

By examining SP data on Misti volcano, segments of constant SP/elevation gradient (Ce) can be easily identified on the profiles in the hydrogeological zone as well as in the hydrothermal zone.

Because $\mathrm{Ce}$ can be linked to the properties of the underlying rocks (see Relationships between SP and elevation), we have undertaken a systematic analysis of the Ce values on all the profiles. This study aims at constructing a map of $\mathrm{Ce}$ values which helps us to

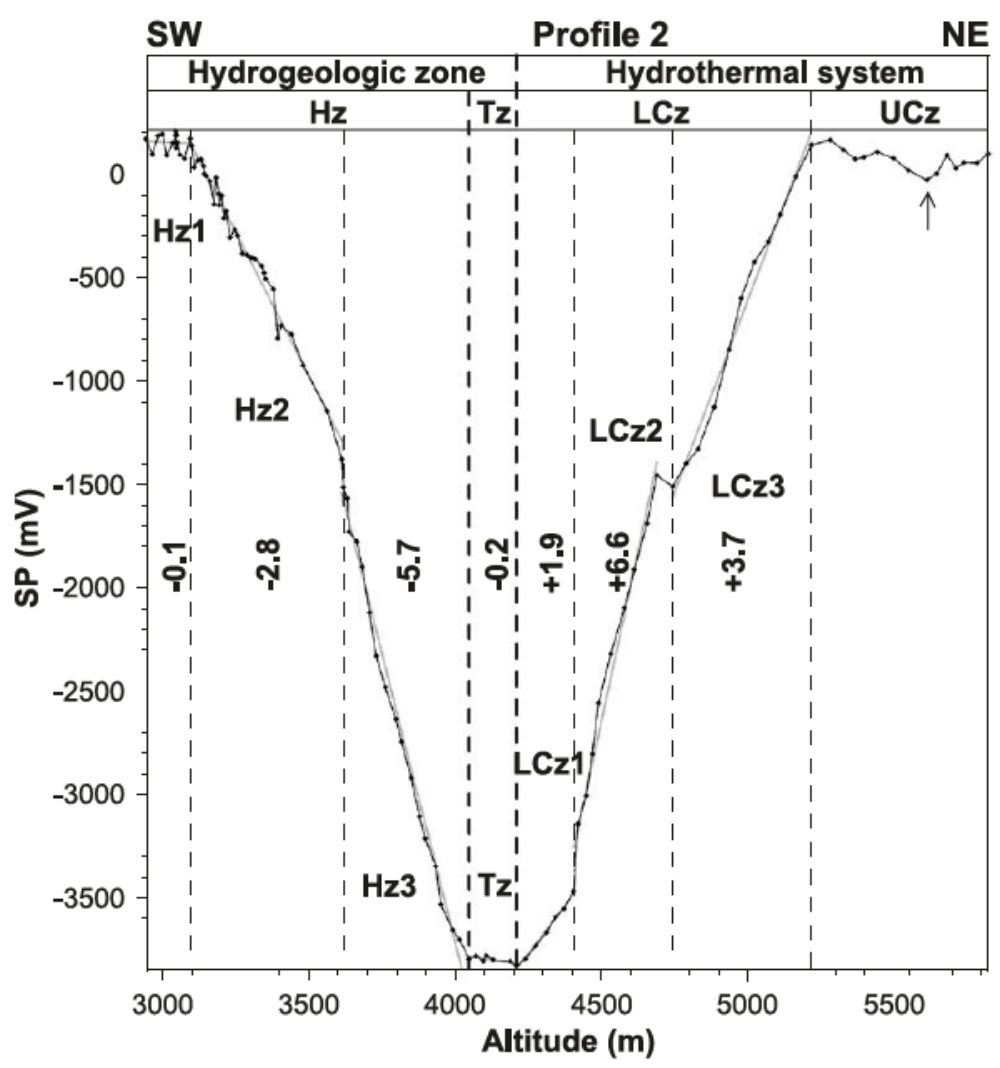

Fig. 5. Plot of SP versus elevation for profile 2. Numbers represent the Ce value for segments of constant SP/elevation gradient (in $\mathrm{mV} \mathrm{m}^{-1}$ ). $\mathrm{Hz}, \mathrm{Tz}, \mathrm{LCz}$, and $\mathrm{UCz}$ stand for 'Hydrogeological zone', 'Transition zone', 'Lower Convective zone', and 'Upper Convective zone', respectively. 
interpret the SP map in terms of internal structures of the volcano.

\subsubsection{Ce map (Fig. 6)}

At the base of the edifice, Ce absolute values are lower than $1 \mathrm{mV} \mathrm{m}^{-1}$. Between the base of the cone and the SP minimum at midslope, the values are about $-2.5 \mathrm{mV} \mathrm{m}^{-1}$, except in some areas where much higher values $\left(-6 \mathrm{mV} \mathrm{m}^{-1}\right)$ are obtained. One large zone of very low Ce is located on the SW flank and two smaller, possibly connected patches are located on the $\mathrm{NE}$ and $\mathrm{E}$ flanks along profiles 6 and 7. Other areas of low Ce exist at the base of the edifice toward the southeast between profiles 5 and 6 , and locally at the beginning of profile 7 .

The transition between the negative $\mathrm{Ce}$ of the hydrogeologic zone and the positive $\mathrm{Ce}$ of the hydrothermal zone may be either very sharp or a few hundred of meters across. This transition occurs at about $4400-4500 \mathrm{~m}$ asl, except on the W and SW flanks where it takes place around $4200 \mathrm{~m}$ asl.

In the hydrothermal zone, high gradients are observed on the SW flank and very high gradients on the west flank, along profile 1 . In the other areas, Ce values vary from moderate (between 1 and $3 \mathrm{mV}$ $\mathrm{m}^{-1}$ ) to very low values, and even locally to negative values. In addition, high $\mathrm{Ce}$ are observed at the base of the edifice, to the $\mathrm{E}$ between profiles 5 and 6 , and to the NE between profiles 7 and 8 .

The Ce map is a complementary tool to analyze SP patterns at the scale of a volcano. If the Ce variations are related to possible changes of the parameters that influence the electrical field generation and propagation, then the Ce map helps to recognize lithologic heterogeneities within the edifice.

\subsubsection{Ce zoning (Fig. 7)}

The example of profile 2 on Fig. 5 allows us to illustrate how the Ce zoning has been defined on the profiles. From the base of the edifice to the SP minimum (at about $4200 \mathrm{~m}$ asl on this profile), three breaks in slope separate four segments: $\mathrm{Hz} 1, \mathrm{~Hz} 2, \mathrm{~Hz} 3$, and Tz ( $\mathrm{Hz}$ and $\mathrm{Tz}$ stand for "Hydrogeological zone" and "Transitional zone" respectively). Above the Tz zone, we enter in the hydrothermal zone, where a succession of segments of constant positive Ce is observed: $\mathrm{LCz} 1$, $\mathrm{LCz} 2$, and $\mathrm{LCz} 3$ ( $\mathrm{LCz}$ stands for "Lower Convective zone"). LCz2 corresponds to the highest Ce values, characterizing the SW quarter of the edifice (Fig. 6). At higher elevation, above $5200 \mathrm{~m}$ asl, the Ce decreases. We have termed this zone $\mathrm{UCz}$ ("Upper Convective zone"). The arrows in the UCz marks the boundary of the summit caldera (Thouret et al., 2001). On almost all the profiles, this limit corresponds to a significant SP minimum (between 100 and $200 \mathrm{mV}$ in amplitude). Based on a similar analysis carried out on all the profiles, the resulting zoning is shown in map on Fig. 7.

\subsection{Resistivity cross-section}

Fig. 3 shows the computed 2D AMT resistivity profile and the SP profile along the same path. Because the 2D inversion tends to provide a smooth distribution of resistivities, the presence of sharper resistivity contrasts cannot be ruled out. However, the main resistivity patterns of the profile are well constrained and these results yield to the resistivity distribution inside the edifice. The shallow layers show high resistivities, characteristic of unsaturated volcanic formations, and the deeper layers show low resistivities which are attributed to water saturation and (or) to hydrothermal alteration. We observe significant lateral variations in the resistivity section along the profile. The first-order feature on Fig. 3 is the apparent association between the steep gradient of SP anomalies and thick sequences of highly resistive formations. Similar observations were made on Usu and Hokkaido Komaga-take volcanoes (Nishida and Tomiya, 1987; Matsushima et al., 1990) and interpreted as lateral variations in electric resistivity responsible for the distortion of the SP field. AMT soundings are lacking in the summit area where the presence of shallow conductive layers would be critical to confirm the existence of hydrothermally altered formations in the SP hydrothermal zone. However, where the SP anomalies reverse and become positive, the AMT resistivity section suggests a significant and sharp decrease in thickness of the highly resistive layers.

\subsection{SP monitoring profile and soil gas measurements}

The pattern of SP variations in time can provide insights into the electrokinetic phenomena within the hydrogeologic and hydrothermal zones. Similarly, measurements of gas emanations can help to charac- 


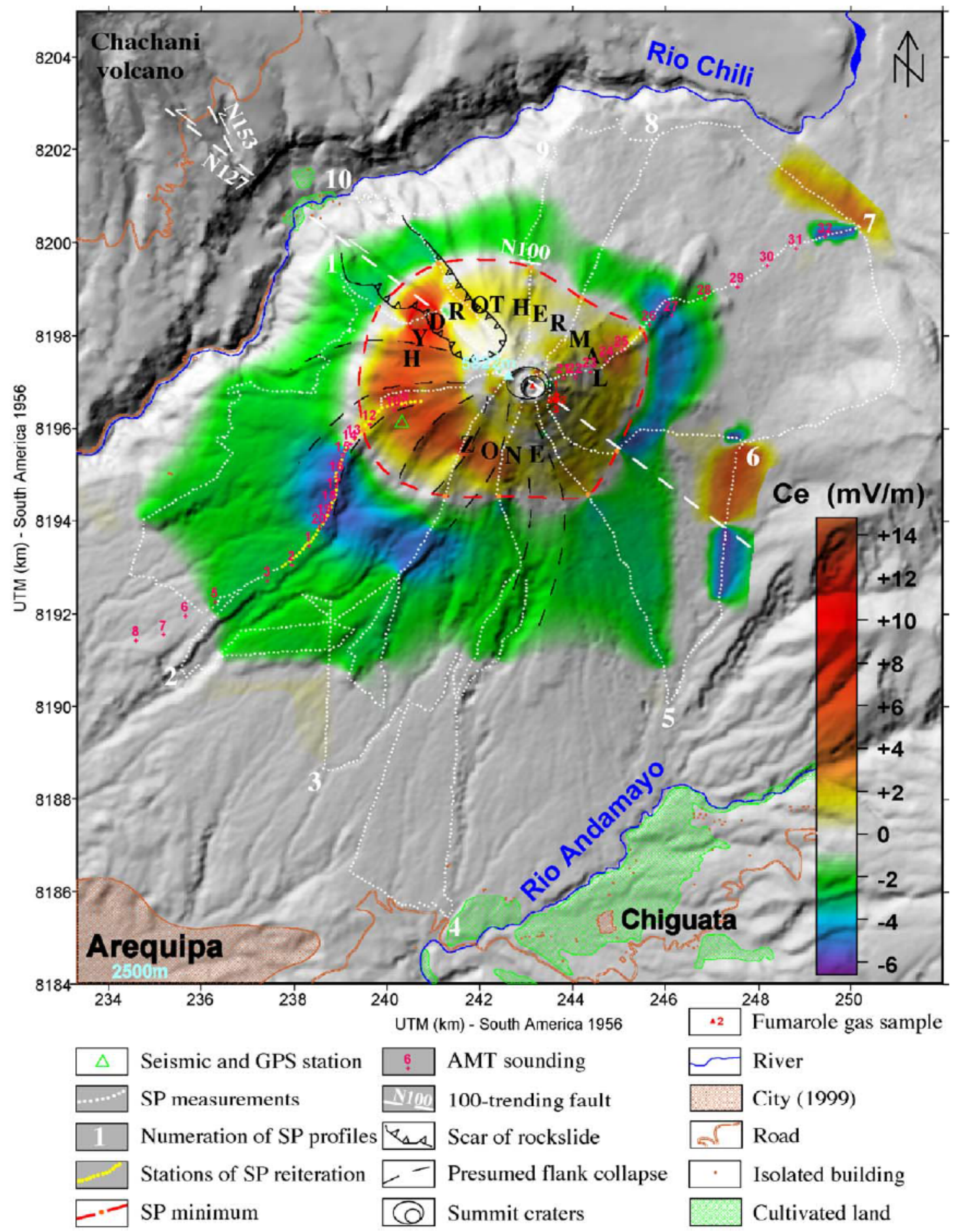

Fig. 6. Distribution of the Ce values mapped on Misti volcano superimposed on a shaded relief map showing volcano-structural features. 


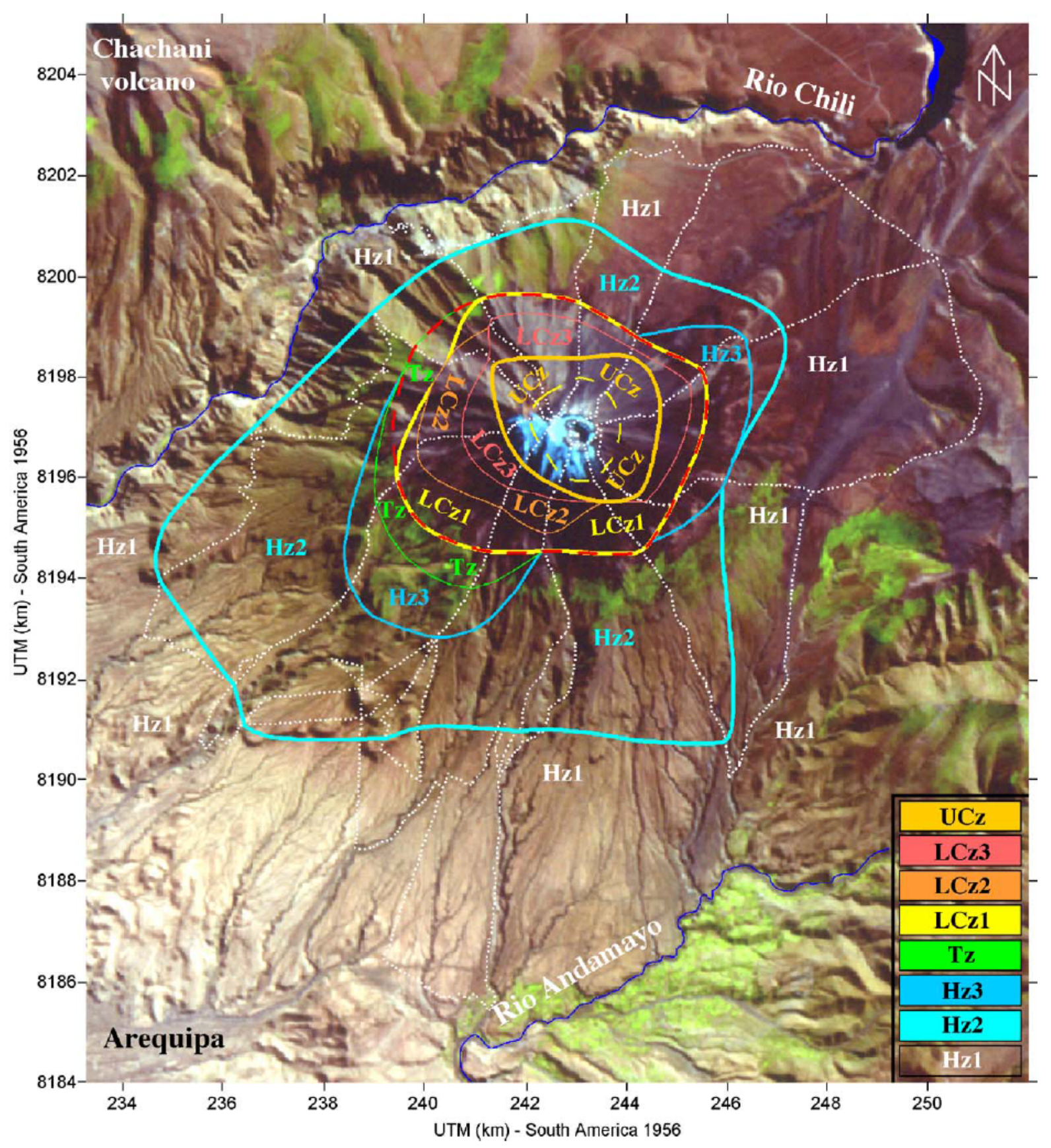

Fig. 7. Ce limits on Misti volcano defined along SP profiles (Figs. 4 and 5) superimposed on a Landsat image. Red and yellow dashed lines represent the SP minimum and the summit caldera defined on Fig. 5. Hz, Tz, LCz, and UCz stand for 'Hydrogeological zone', 'Transition zone', 'Lower Convective zone', and 'Upper Convective zone', respectively. 


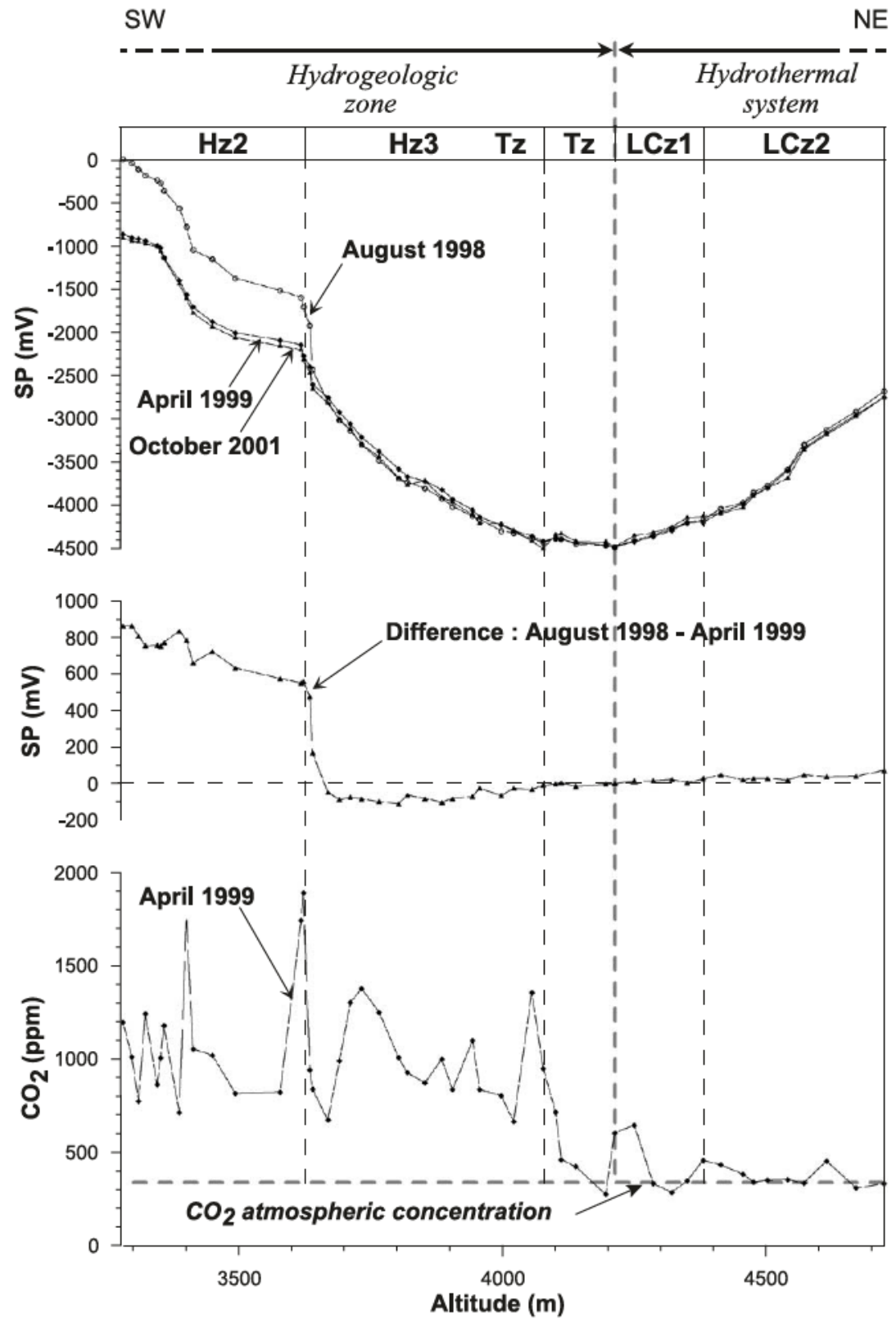

Fig. 8. $\mathrm{SP}$ and $\mathrm{CO}_{2}$ soil gas measurements along the 52 monitoring stations located on Misti along the profile 2 (see Fig. 2).

terize the geometry of fluid flow and to interpret the SP observations. For those reasons, we have measured $\mathrm{CO}_{2}$ concentrations in the soil along an SP monitoring profile.

The monitoring SP profile comprises 52 stations distributed along profile 2 (Fig. 2). It was installed in
August 1998 and remeasured in April 1999 and October 2001. The stations are marked by benchmarks to ensure that the measurements are made at the same locations. In order to compare the amplitude changes between the hydrothermal and the hydrogeologic system, the SP minimum measured in August 1998 is 
taken here as a common reference (Fig. 8). However, because SP is intrinsically a relative measurement, the variations should be regarded as relative unless a stable reference is available (sea, water table). The variations were very small between April 1999 and October 2001 but increased significantly between August 1998 and April 1999. The three curves show almost no change in the hydrothermal system and in the transition zone. In addition to showing a stable SP in this area, this observation indicates that the measurements can be repeated with an excellent accuracy (the difference between one measurement and the average of the three years is $<40 \mathrm{mV}$ ). Changes are seen in the hydrogeologic zone but the amplitude of the changes are very different according to the Ce values. In the zone called $\mathrm{Hz3}$, the changes are small and negative between August 1998 and April 1999, but in the zone $\mathrm{Hz} 2$, the changes are significantly higher and positive. The amplitude of the SP variations is clearly related to the $\mathrm{Ce}$ zoning. The $\mathrm{Hz} 2$ zone $\mathrm{Ce}$ changed from -5.4 to $-4.5 \mathrm{mV} \mathrm{m}^{-1}$ between August 1998 and April 1999. However, without a stable reference, we do not know if the SP has increased between 600 to 800 $\mathrm{mV}$ in $\mathrm{Hz} 2$ zones or if the changes occur in other zones.

The $\mathrm{CO}_{2}$ measurements were carried out in April 1999. Fig. 8 shows the comparison between the SP and $\mathrm{CO}_{2}$ signals. Strikingly, the $\mathrm{CO}_{2}$ signal is significantly higher than atmosphere concentrations on the lower flank in the hydrogeologic zone, whereas the $\mathrm{CO}_{2}$ emanations vanish above the hydrothermal zone. Similar results were obtained on Stromboli volcano (Finizola, 2002). The transition between the two zones is rapid on both volcanoes and suggests a relationship between the lack of $\mathrm{CO}_{2}$ emanations and the presence of a hydrothermal system. Sealing processes in the hydrothermal system can create impermeable layers that block the upward migration of gases. At the summit, however, permeable conduits exist near the craters, enabling the escape of gases. Samples collected

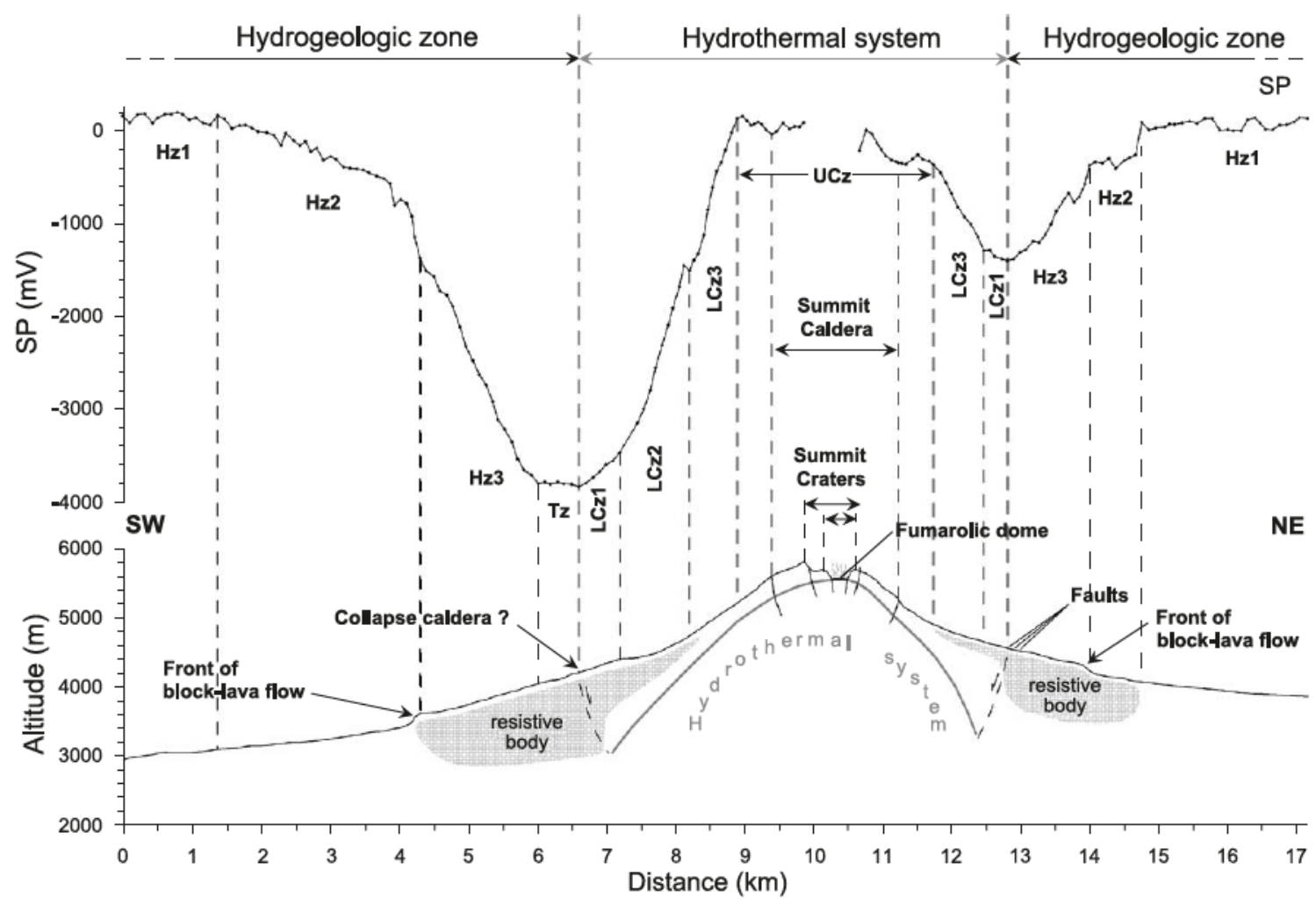

Fig. 9. SP signal along a NE-SW transect (profiles 2 and 7) and interpretative cross-section of Misti volcano. 
at the five fumaroles on the dome and eastward of the crater (Fig. 2) yield much higher $\mathrm{CO}_{2}$ concentrations than on the lower flanks (several percents of $\mathrm{CO}_{2}$ ).

The elongated fumarole field at the summit parallels the normal WNW-ESE trending normal fault (N127 in Fig. 2). Rockslides occur in a trough which parallels this fault on the west-northern flank (Thouret et al., 2001) where collapses are interpreted as resulting from the reactivation of this regional fault (Merle et al., 2001).

\section{Interpretation}

For the first time, a complete SP mapping of a large andesitic stratovolcano is available. This exceptional data set can be used to characterize the main SP features at the scale of a large edifice. Using the additional information from AMT and $\mathrm{CO}_{2}$ data, a new picture of the structure of the edifice is proposed. We have to take into account and to explain the following observations:

- Ce values (negative in the hydrogeologic zone and positive in the hydrothermal zone) vary to a large extent in the survey areas. These variations are not progressive but are marked by generally sharp and large Ce variations. These characteristics suggest the role, influence of lithologic discontinuities.

- Clearly defined positive $\mathrm{Ce}$ in areas of the hydrothermal zone suggests some kind of relationship between the hydrothermal system and the elevation.

- Some areas on the cone $(\mathrm{Hz} 3)$ are characterized by particularly high Ce values (generally $>4 \mathrm{mV} \mathrm{m}^{-1}$ in absolute value). They are associated with layers showing high electrical resistivity.

- The hydrothermal and the hydrogeologic zones are composed of roughly concentric zones of constant Ce values.

- $\mathrm{CO}_{2}$ emanations along the $\mathrm{SW}$ radial profile suggest that the hydrothermal zone is partially sealed by hydrothermal alteration processes.

\subsection{Relationships between Ce limits and lithology}

The difficulty in interpreting the Ce zones on Misti stems from the fact that the distinct in situ parameters which contribute to generate the SP at the surface are unknown. Therefore, we do not know whether the welldefined Ce values characterize the medium at depth or reflect only the properties of the superficial terrains.

The Ce boundaries can be compared with the resistivity section and, on the lower flanks, compared with surface geology. The AMT resistivity section (Fig. 3) suggests that some Ce variations are associated with the two main resistive bodies at the base of the cone along the AMT profile (Fig. 9). However, the resistivity data are not dense and detailed enough to allow us to establish unambiguous correlations between the resistivity of the terrains and the lower amplitude Ce changes.

In the hydrogeologic zone, one of the main questions lies in the sharp limit between hydrogeologic zones 1 and 2 ( $\mathrm{Hzl}$ and $\mathrm{Hz} 2$ ). A detailed contour analysis of this limit on Fig. 7 shows a coincidence with the front of stubby lava lows and block lava flows from the Misti 2 stage. Therefore, the $\mathrm{Hz} 1-\mathrm{Hz} 2$ limit may be related to a change in surface geology. Similarly, the Hz3 limit may correspond to the fronts of thick Misti 3 block-lava flows. Therefore, the $\mathrm{Hz} 1-\mathrm{Hz} 2$ and $\mathrm{Hz} 2-\mathrm{Hz} 3$ transitions are apparently related to geologic boundaries and suggest a general relationship between $\mathrm{Ce}$ boundaries and geologic boundaries.

In the hydrothermal system, similar Ce transitions correspond to the successive $\mathrm{LCz} 1, \mathrm{LCz} 2, \mathrm{LCz} 3$, and $\mathrm{UCz}$ zones. Considering the large extent of the hydrothermal system (5-6 km in diameter), and the sharpness of the changes in Ce which usually occur over a short distance (less than $100 \mathrm{~m}$ ), the presence of shallow heterogeneities would explain the $\mathrm{Ce}$ transitions.

Interestingly, after several raining seasons with drastic differences in water supply, such as the dry 1997-1998 as opposed to the normal 1998-1999 and 2000-2001 ones, the changes in the SP signal (Fig. 8) are not homogeneous along the profile but are segmented in coincidence with $\mathrm{Ce}$ transitions. These results emphasize the importance of the Ce parameter. Different shallow lithologies can induce distinct water infiltration, thus promoting differential SP response.

This interpretation of $\mathrm{Ce}$ changes in term of lateral lithologic transitions can help to interpret previous and future SP works on active volcanoes. It is, however, important to note that this SP analysis on 
Misti volcano was helped by (1) an SP signal with a clear signal/noise ratio, and (2) obvious shallow lithologic discontinuities allowing to draw a relationship with Ce transitions.

\subsection{Craters and calderas}

SP surveys carried out on volcanoes, such as Pico del Teide (Aubert and Kieffer, 1984), Mount Pelée (Zlotnicki et al., 1998), or Stromboli (Finizola, 2002), suggest that caldera faults preferentially drain water infiltration, reflected by sharp negative SP anomalies, generally of few hundreds of millivolt in amplitude. On the other hand, caldera or crater walls, e.g., at Karthala (Lénat et al., 1998) or Stromboli (Finizola, 2002), can also block the lateral extent of hydrothermal systems.

At Misti, two calderas (Fig. 9) are suggested by geologic studies (Thouret et al., 2001). The summit caldera, formed at about $14-11 \mathrm{kyr}$, is based on geological evidence. An older (40-50 kyr) and larger collapse caldera is suspected on the base of morphological change in the slope of the cone, faults observed on the north flank, and on ignimbrites resulting from caldera forming eruptions (on the SW, S, and SE flanks of Misti).

The coincidence on most profiles between the summit caldera boundary (represented on profile 2 by an arrow on Fig. 5) and a more or less marked short wavelength SP anomaly suggests that SP signal indicates an effect of the caldera boundary (Fig. 7). However, the SP-defined hydrothermal zone clearly exceeds these limits. The outer limit of the SP hydrothermal zone is reflected by the Transitional zone $(\mathrm{Tz}$ ), when present, or by the $\mathrm{Hz} 3$ (or $\mathrm{Hz} 2$ )$\mathrm{LCz} 1$ limit. The extent of the hydrothermal zone coincides with the inferred location of the 40-50ka-old caldera. These observations suggest that this suspected structural boundary can block the lateral extent of the present-day hydrothermal system of Misti.

\subsection{Existence of well-defined positive Ce in the hydrothermal zone}

A constant positive gradient of SP with elevation occurs in some areas of the geothermal zone. While the negative $\mathrm{Ce}$ in hydrogeological zones have been satisfactorily explained, positive Ce have not. As the fluid flow is assumed to be upward, a linear correlation between SP and altitude is difficult to explain. One possible explanation is that the depth of the SP sources decreases linearly with the elevation. In other words, the hydrothermal system becomes shallower as we approach the summit and the decrease in depth would be, for some reason, linearly linked to the variations in elevation. This hypothesis is qualitatively concordant with the results displayed by the resistivity cross-section (Fig. 3).

\subsection{The general structure of Misti}

From an SP point of view, Misti volcano exhibits a typical pattern with a hydrogeologic zone on its lower flanks and a hydrothermal zone in its central area. However, the SP signal reveals large-scale heterogeneities in the cone. They are evidenced by the distribution of the $\mathrm{Ce}$ values. The $\mathrm{Ce}$ zones form a concentric pattern around the summit. The transition between the Ce zones is thought to be created by lateral variations of resistivities showing the contact between distinct formations within the edifice. The highest amplitudes of the SP anomalies seem to coincide with highly resistive zones. The hydrothermal zone has a significantly larger extent than the present and recent summit active area. This suggests a broad and long-lived hydrothermal system, possibly developed in an old collapse structure. The $\mathrm{CO}_{2}$ measurements indicate that $\mathrm{CO}_{2}$ emanations are virtually absent above the hydrothermal zone (except in and close to the summit crater) whereas they show significant values on the lower flanks. Such a pattern has been observed on other volcanoes (Williams-Jones et al., 2000) and is interpreted by the sealing of the medium by the hydrothermal circulation. The limit of the inferred sealed zone coincides with that of the extent of the hydrothermal system defined by SP data.

\section{Conclusions}

Our geophysical and geochemical work on Misti volcano is based on new data: a large SP data set, an AMT profile across the volcano, and $\mathrm{CO}_{2}$ concentrations in the soil along a radial profile and at the summit fumaroles. The SP survey is the first in providing a 
complete map of a large andesitic stratovolcano. We have therefore carried out an extensive study of the SP signatures associated to this type of active volcano. Some results of this survey can serve as a guide to further geological and geophysical investigations on Misti and on other composite cones as well.

Clear relationships between the SP and the elevation have been observed in both the hydrogeologic and hydrothermal zones. Their detailed analysis provided information on the lateral heterogeneities of the edifices. This work demonstrates that the analysis of the $\mathrm{Ce}$ is a useful tool for interpreting an SP map.

The two major results are the existence of both negative and positive linear SP/altitude gradients (Ce) and of zones of different values of $\mathrm{Ce}$.

A sealed zone has apparently developed through alteration in the hydrothermal system, blocking the upward migration of $\mathrm{CO}_{2}$. Similar observations was made on other stratovolcanoes (Williams-Jones et al., 2000; Finizola, 2002). We suspect that the sealing of hydrothermal system is widespread on volcanoes where long-lived hydrothermal systems exist.

\section{Acknowledgements}

We thank Jaime Suni, Rachel Gusset, Pedro Navarro, Katherine Gonzales, Vicentina Cruz, Señor Uribe, and Victor Montesinos for their help during the 1997 and 1998 field campaigns. This work was supported by the Institut de Recherche pour le Développement (IRD) and the Instituto Geofisico del Perú (IGP). Reviews by H.M. Bibby and an anonymous reader have considerably helped to improve the manuscript. We also thank Laurence Jouniaux, Xavier Guichet, and André Revil for interesting discussions and remarks. A.F. acknowledges Jean-Luc Froger in providing the DEM of Misti volcano improved by SAR-interferometry, Benjamin Van Wyk de Vries for the Landsat image of Misti area, and the "Société de Secours des Amis des Sciences" for a research grant.

\section{References}

Aubert, M., Dana, I., 1994. Interpretation of the self-potential radial profiles in volcanology: possibilities of the SP method for the monitoring of the active volcanoes. Bull. Soc. Geol. Fr. $2,113-122$.
Aubert, M., Kieffer, G., 1984. Evolution d'une intrusion magmatique dans le flanc sud de l'Etna entre juin 1982 et juin 1983. Résultats de potentiel spontané (PS) et essai d'interprétation de l'éruption de 1983. C. R. Acad. Sci. Paris t.296 (Série II-8), 379-382.

Aubert, M., Dana, I.N., Livet, M., 1990. Vérification de limites de nappes aquiféres en terrain volcanique par la méthode de polarisation spontanée. C. R. Acad. Sci., Paris 311 (II), 999-1004.

Aubert, M., Dana, I.N., Gourgaud, A., 2000. Internal structure of the Merapi summit from self-potential measurements. J. Volcanol. Geotherm. Res. 100, 337-343.

Avena, M.J., De Pauli, C.P., 1996. Modeling the interfacial properties of an amorphous aluminosilicate dispersed in aqueous $\mathrm{NaCl}$ solutions. Colloids Surf. 118, 75-87.

Boubekraoui, S., Courteaud, M., Aubert, M., Albouy, Y., Coudray, J., 1998. New insights into the hydrogeology of a basaltic shield volcano from a comparison between self-potential and electromagnetic data: Piton de la Fournaise, Indian Ocean. J. Appl. Geophys. 40, 165-177.

Bullard, F.M., 1962. Volcanoes of southern Peru. Bull. Volcanol. $24,443-453$.

Corwin, R.F., Hoover, D.B., 1979. The self-potential method in geothermal exploration. Geophysics 44-2, 226-245.

de Silva, S.L., Francis, P.W., 1990. Active and potentially active volcanoes of southern Peru: observations using Landsat Thematic Mapper and space shuttle imagery. Bull. Volcanol. 52, 286-301.

Di Maio, R., Mauriello, P., Patella, D., Petrillo, Z., Piscitelli, S., Siniscalchi, A., 1998. Electric and electromagnetic outline of the Mount Somma-Vesuvius structural setting. J. Volcanol. Geotherm. Res. 82, 219-238.

Dobrin, M.B., Savit, C.H., 1988. Introduction to Geophysical Prospecting. McGraw-Hill Book, New York. 867 pp.

Finizola, A., Sortino, F., Lénat, J.-F., Valenza, M., 2002. Fluid circulation at Stromboli volcano, (Aeolian Islands, Italy) from self-potential and soil gas surveys. J. Volcanol. Geotherm. Res. 116 (1-2), 1-18.

Fournier, C., Méthodes géoélectriques appliquées à l'hydrogéologie en région volcanique (Chaîne des Puys, Massif Central français). Développement de la méthode des potentiels spontanés en hydrogéologie. $\mathrm{PhD}$ thesis. Univ. Montpellier.

Guichet, X., Zuddas, P., 2003. Effect of secondary minerals on electrokinetic phenomena during water-rock interaction. Geophys. Res. Lett. 30 (13), 1714 (doi: 10.1029/2003GL017480).

Guichet, X., Jouniaux, L., Pozzi, J.-P., 2003. Streaming potential of a sand column in partial saturation conditions. J. Geophys. Res. 108 (B3), 2141 (doi: 10.1029/2001JB001517).

Ishido, T., Mizutani, H., 1981. Experimental and theoretical basis of electrokinetic phenomena in rock-water systems and its applications to geophysics. J. Geophys. Res. 86, 1763-1775.

Jackson, D.B., Kauahikaua, J., 1987. Regional self-potential anomalies at Kilauea volcano. Volcanism in Hawaii. USGS Professional paper, vol. 1350, pp. 947-959. Chap. 40.

Jouniaux, L., Bernard, M.L., Zamora, M., Pozzi, J.P., 2000. Streaming potential in volcanic rocks from Mount Pelée. J. Geophys. Res. 105 (4), $8391-8401$.

Lénat, J.F., 1987. Structure et dynamique interne d'un volcan basal- 
tique intraplaque océanique: Le Piton de la Fournaise (ile de la Réunion). Thése de doctorat és sciences. Univ. Blaise Pascal, Clermont-Ferrand. France.

Lénat, J.F., Robineau, B., Durand, S., Bachélery, P., 1998. Etude de la zone sommitale du volcan Karthala (Grande Comore) par polarisation spontanée. C. R. Acad. Sci. 327, 781-788.

Lorne, B., Perrier, F., Avouac, J.P., 1999a. Streaming potential measurements: 1. Properties of the electrical double layer from crushed rock samples. J. Geophys. Res. 104, 17857-17877.

Lorne, B., Perrier, F., Avouac, J.P., 1999b. Streaming potential measurements: 2. Relationship between electrical and hydraulic flow patterns from rock samples during deformation. J. Geophys. Res. 104, 17879-17896.

Malengreau, B., Lénat, J.F., Bonneville, A., 1994. Cartographie et surveillance temporelle des anomalies de Polarisation Spontanée (PS) sur le Piton de la Fournaise. Bull. Soc. Géol. Fr. 165 (3), $221-232$.

Matsushima, N., Michiwaki, M., Okazaki, N., Ichikawa, N., Takagi, A., Nishida, Y., Mori, H.Y., 1990. Self-potential study in volcanic areas-Usu, Hokkaido Komaga-take and Me-akan. J. Fac. Sci., Hakkaido Univ., Ser. VII (Geophysics) 8 (5), $465-477$.

Merle, O., Vidal, N., Van Wyk de Vries, B., 2001. Experiments on vertical basement fault reactivation below volcanoes. J. Geophys. Res. 106 (B2), 2153-2162.

Michel, S., Zlotnicki, J., 1998. Self-potential and magnetic surveying of La Fournaise Volcano (Reunion Island): correlations with faulting, fluid circulation, and eruption. J. Geophys. Res., B 103 (8), 17845-17857.

Nishida, Y., Tomiya, H., 1987. Self-potential studies in volcanic areas-Usu volcano. J. Fac. Sci., Hokkaido Univ., Ser. VII Geophysics 8-2, 173-190.

Pengra, D.B., Li, S.X., Wong, P.-Z., 1999. Determination of rock properties by low-frequency AC electrokinetics. J. Geophys. Res. 104, 29485-29508.

Pride, S.R., 1994. Governing equations for the coupled electromagnetics and acoustics of porous media. Phys. Rev. B 50, $15678-15696$.

Pride, S.R., Morgan, F.D., 1991. Electrokinetic dissipation induced by seismic waves. Geophysics $56,914-925$.

Revil, A., Leroy, P., 2001. Hydroelectric coupling in a clayey material. Geophys. Res. Lett. 28, 1643-1646.

Revil, A., Pezard, P.A., Glover, P.W.J., 1999a. Streaming potential in porous media: 1 . Theory of the zeta potential. J. Geophys. Res. 104, 20021-20031.

Revil, A., Schwaeger, H., Cathles, L.M., Manhardt, P.D., 1999 b. Streaming potential in porous media: 2 . Theory and application to geothermal systems. J. Geophys. Res. 104, 20033-20048.
Revil, A., Hermitte, D., Spangenberg, E., Cocheme, J.J., 2002. Electrical properties of zeolitized volcaniclastic materials. J. Geophys. Res., B, Solid Earth Planet. 107 (8), 2168-2184. (doi: 10.1029/2001JB000599)

Revil, A., Hermitte, D., Voltz, M., Moussa, R., Lacas, J.-G., Bourrié, G., Trolard, F., 2002b. Self-potential signals associated with variations of the hydraulic head during an infiltration experiment. Geophys. Res. Lett. 29.

Revil, A., Naudet, V., Nouzaret, J., Pessel, M., 2003. Principles of electrography applied to self-potential electrokinetic sources and hydrogeological applications. Water Resour. Res. 36 (5), 3-1-3-15.

Sasai, Y., Zlotnicki, J., Nishida, Y., Yvetot, P., Morat, P., Hurukami, H., Tanaka, Y., Ishikawa, Y., Koyama, S., Sekigushi, W., 1997. Electromagnetic monitoring of Miyake-jima volcano, Izu-Bonin Arc, Japan: a preliminary report. J. Geomagn. Geoelectr. 49, 1293-1316.

Thouret, J.C., Finizola, A., Fornari, M., Legeley-Padovani, A., Suni, J., Frechen, M., 2001. Geology of El Misti volcano near the city of Arequipa, Peru. Geol. Soc. Amer. Bull. 113,12, 1593-1610.

Trique, M., Richon, P., Perrier, F., Avouac, J.P., Sabroux, J.C., 1999. Radon emanation and electrical potential variations associated with transient deformation near reservoir lakes. Nature $399,137-141$.

Vozoff, K., 1991. The magnetotelluric method. In: Nabighian, M.N. (Ed.), Electromagnetic Methods in Applied Geophysics. Soc. Explor. Geophys., Tulsa, OK, pp. 641-711.

Williams-Jones, G., Stix, J., Heiligmann, M., Charland, A., Sherwood Lollar, B., Arner, N., Garzon, G., Barquero, J., Fernandez, E., 2000. A model of diffuse degassing at three subductionrelated volcanoes. Bull. Volcanol. 62, 130-142.

Zablocki, C.J., 1976. Mapping thermal anomalies on an active volcano by the self-potential method, Kilauea, Hawaii. Proceedings, 2nd U.N. Symposium of the Development and Use of Geothermal Resources, San Francisco, California, May 1975, vol. 2. U.S. Govt. Printing Office, Washington, DC, pp. 1299-1309.

Zablocki, C.J., 1978. Streaming potentials resulting from the descent of meteoric water: a possible source mechanism for Kilauean self-potential anomalies. Geothermal energy: a novelty becomes resource. Geotherm. Resour. Counc., Davis, Calif. United States (USA), Hilo, Hawaii, United States, 747-748.

Zlotnicki, J., Boubon, G., Viodé, J.P., Delarue, J.F., Mille, A., Bruére, F., 1998. Hydrothermal circulation beneath Mount Pelée inferred by self potential surveying. Structural and tectonic implications. J. Volcanol. Geotherm. Res. 84, 73-91. 